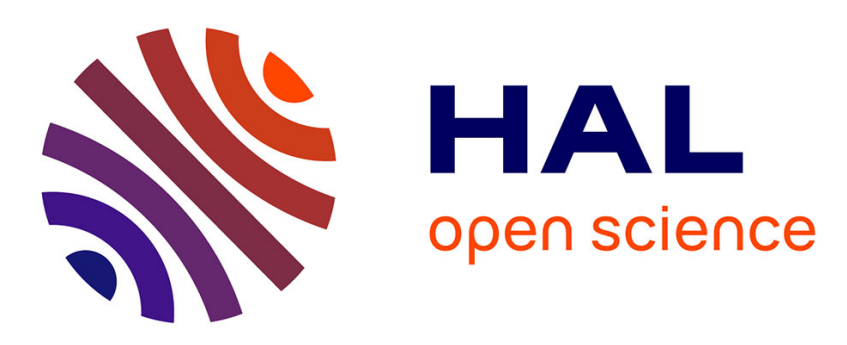

\title{
Ketone bodies and islet function : 86Rb handling and metabolic data
}

W.J. Malaisse, P. Lebrun, J. Rasschaert, Francois F. Blachier, Tuncay Yilmaz, A. Sener

\section{- To cite this version:}

W.J. Malaisse, P. Lebrun, J. Rasschaert, Francois F. Blachier, Tuncay Yilmaz, et al.. Ketone bodies and islet function: 86Rb handling and metabolic data. AJP - Endocrinology and Metabolism, 1990, 22 (1), pp.E123-E130. hal-02705911

\section{HAL Id: hal-02705911 \\ https://hal.inrae.fr/hal-02705911}

Submitted on 1 Jun 2020

HAL is a multi-disciplinary open access archive for the deposit and dissemination of scientific research documents, whether they are published or not. The documents may come from teaching and research institutions in France or abroad, or from public or private research centers.
L'archive ouverte pluridisciplinaire HAL, est destinée au dépôt et à la diffusion de documents scientifiques de niveau recherche, publiés ou non, émanant des établissements d'enseignement et de recherche français ou étrangers, des laboratoires publics ou privés. 


\section{Ketone bodies and islet function: 86Rb handling and}

metabolic data

W. J. Malaisse, P. Lebrun, J. Rasschaert, F. Blachier, T. Yilmaz and A. Sener

Am J Physiol Endocrinol Metab 259:E123-E130, 1990. ;

You might find this additional info useful...

This article has been cited by 2 other HighWire-hosted articles:

http://ajpendo.physiology.org/content/259/1/E123\#cited-by

Updated information and services including high resolution figures, can be found at: http://ajpendo.physiology.org/content/259/1/E123.full

Additional material and information about American Journal of Physiology - Endocrinology and Metabolism can be found at:

http://www.the-aps.org/publications/ajpendo

This information is current as of January 24, 2013.

American Journal of Physiology - Endocrinology and Metabolism publishes results of original studies about endocrine and metabolic systems on any level of organization. It is published 12 times a year (monthly) by the American Physiological Society, 9650 Rockville Pike, Bethesda MD 20814-3991. Copyright (C) 1990 the American Physiological Society. ISSN: 0193-1849, ESSN: 1522-1555. Visit our website at http://www.the-aps.org/. 


\title{
Ketone bodies and islet function: ${ }^{86} \mathrm{Rb}$ handling and metabolic data
}

\author{
WILLY J. MALAISSE, PHILIPPE LEBRUN, JOANNE RASSCHAERT, \\ FRANÇOIS BLACHIER, TEMEL YILMAZ, AND ABDULLAH SENER \\ Laboratory of Experimental Medicine, Brussels Free University, B-1000 Brussels, Belgium
}

\begin{abstract}
Malaisse, Willy J., Philippe Lebrun, Joanne RasSCHAERT, François Blachier, Temel Yilmaz, AND ABDUlLAH SENER. Ketone bodies and islet function: ${ }^{86} \mathrm{Rb}$ handling and metabolic data. Am. J. Physiol. 259 (Endocrinol. Metab. 22): E123-E130, 1990.-The metabolism of ketone bodies was investigated in rat pancreatic islets incubated in the absence or presence of $\mathrm{D}$-glucose. The generation of ${ }^{14} \mathrm{CO}_{2}$ from $3-{ }^{14} \mathrm{C}$ labeled ketone bodies, the interconversion of $\mathrm{D}-(-)-\beta$-hydroxybutyrate and acetoacetate (AcAc), the reciprocal effects of ketone bodies and D-glucose on their respective catabolism, and the influence of these exogenous nutrients on the output of ${ }^{14} \mathrm{CO}_{2}$ from islets preincubated with either L-[U- $\left.{ }^{14} \mathrm{C}\right]$ glutamine or $\left[\mathrm{U}-{ }^{14} \mathrm{C}\right]$ palmitate provided an estimation of the nutrient-induced changes in $\mathrm{O}_{2}$ uptake that was in fair agreement with the observed modifications of islet respiration. There was a close correlation between such changes and the corresponding values for insulin output. Because the stimulation of insulin release by ketone bodies also coincided with a decrease in ${ }^{86} \mathrm{Rb}$ outflow from prelabeled islets, these findings suggest that the insulinotropic action of ketone bodies is causally linked to their catabolism through an increase in ATP generation rate and a subsequent decrease in $\mathrm{K}^{+}$conductance. A complementary participation of changes in mitochondrial redox state to stimulussecretion coupling is considered, however, in the light of comparisons between the effects of $\mathrm{D}-(-)-\beta$-hydroxybutyrate and AcAc, respectively, on mitochondrial $\mathrm{NADH}$ generation, ${ }^{45} \mathrm{Ca}$ net uptake, and $\mathrm{D}-\left[6{ }^{-14} \mathrm{C}\right]$ glucose oxidation.
\end{abstract}

pancreatic islets; D-(-)- $\beta$-hydroxybutyrate; acetoacetate; rubidium-86

THE EFFECTS of ketone bodies on insulin release, calcium handling, and biosynthetic activity in pancreatic islets are compatible with the view that the insulinotropic action of these nutrients may be causally linked to their catabolism in the islets (26). Such a hypothesis was further investigated in the present study by exploring both the metabolism of ketone bodies in isolated rat islets and the resulting changes in ${ }^{86} \mathrm{Rb}$ outflow from prelabeled islets.

\section{MATERIALS AND METHODS}

D- $(-)-\beta$-Hydroxy- $\left[3-{ }^{14} \mathrm{C}\right]$ butyrate $\left\{\mathrm{D}-(-)-\beta-\left[3-{ }^{14} \mathrm{C}\right]-\right.$ $\mathrm{OHB}\}$ and ethyl $\left[3-{ }^{14} \mathrm{C}\right]$ acetoacetate were purchased from Amersham (Buckinghamshire, UK). The $\left[{ }^{14} \mathrm{C}\right]$ acetoacetate (AcAc) was freshly prepared from its ester, in the presence of unlabeled ethyl AcAc, as described in the preceding report (26).

All experiments were performed with islets prepared from fed female Wistar albino rats (32). The methods used to measure the uptake of nutrients (37), their oxidation (9) and their effects on $\mathrm{O}_{2}$ consumption $(6,36)$, and the output of ${ }^{14} \mathrm{CO}_{2}$ from islets prelabeled with either $\left[\mathrm{U}-{ }^{14} \mathrm{C}\right]$ palmitate $(38)$ or L- $\left[\mathrm{U}-{ }^{14} \mathrm{C}\right]$ glutamine $(30,40)$ are described in the cited references. In the measurement of $\left[3-{ }^{14} \mathrm{C}\right] \mathrm{AcAc}$ oxidation, which was made with groups of $20-25$ islets each, the blank value was unusually high, representing $0.81 \pm 0.19 \%(n=4)$ of the total radioactive content of the incubation media $(40 \mu \mathrm{l})$. The incorporation of metabolic poisons ( $\mathrm{KCN}, 5.0 \mathrm{mM}$ and antimycin A, $0.01 \mathrm{mM}$ ) in the incubation medium failed to decrease such a blank value. The procedures used to measure the generation of $\left[{ }^{14} \mathrm{C}\right] \mathrm{AcAc}(16)$ and the efflux of ${ }^{86} \mathrm{Rb}$ from prelabeled islets (8) were also previously reported.

To measure the content of the islets and incubation media in $\mathrm{D}-(-)-\beta$-hydroxybutyrate $[\mathrm{D}-(-)-\beta-\mathrm{OHB}]$, groups of 40 islets each were incubated for $120 \mathrm{~min}$ at $37^{\circ} \mathrm{C}$ in $40 \mu \mathrm{l}$ of our usual bicarbonate-buffered medium (32). The incubation was halted by addition of $10 \mu \mathrm{l}$ perchloric acid (PCA; $12.5 \%, \mathrm{vol} / \mathrm{vol})$ and, after freezing in liquid $\mathrm{N}_{2}$, the islets were disrupted by mechanical agitation (23). After heating for $5 \mathrm{~min}$ at $85^{\circ} \mathrm{C}$ and centrifugation for $3 \mathrm{~min}$ at 5,000 g, aliquots of the PCA extract $(40 \mu \mathrm{l})$ were neutralized with $20 \mu \mathrm{l}$ of a solution of $\mathrm{KOH}(1.0 \mathrm{M})$ and tris(hydroxymethyl)aminomethane (Tris; $0.2 \mathrm{M}$ ) and stored at $-20^{\circ} \mathrm{C}$. The next day, the samples were again centrifuged, and aliquots of the supernatant solution $(40 \mu \mathrm{l})$ were mixed with $30 \mu \mathrm{l}$ Tris. $\mathrm{HCl}$ buffer (100 mM, pH 8.5) containing EDTA (2.6 $\mathrm{mM})$, hydrazinium hydroxide $(1.0 \mathrm{M}), \mathrm{NAD}^{+}(1.0 \mathrm{mM})$, and $\beta$-hydroxybutyrate dehydrogenase $(0.15 \mathrm{U} / \mathrm{ml})$ from Rhodopseudomonas spheroides (Boehringer, Mannheim, FRG). After 60 -min incubation at $20^{\circ} \mathrm{C}$, the reaction was halted by heating for $10 \mathrm{~min}$ at $65^{\circ} \mathrm{C}$. After addition of $140 \mu \mathrm{l} N$-2-hydroxyethylpiperazine- $N^{\prime}$-2-ethanesulfonic acid (HEPES)- $\mathrm{NaOH}$ buffer $(100 \mathrm{mM}, \mathrm{pH} 7.0)$ containing ammonium acetate $(100 \mathrm{mM}), \operatorname{ADP}(1.0 \mathrm{mM}), 2$ ketoglutarate $(0.1 \mathrm{mM})$ mixed with a tracer amount of 2 -[U- $\left.{ }^{14} \mathrm{C}\right]$ ketoglutarate, and beef liver glutamate dehydrogenase $(6 \mathrm{U} / \mathrm{ml}$; Boehringer) and further incubation for $30 \mathrm{~min}$ at $20^{\circ} \mathrm{C}$, the reaction was halted by addition of $0.9 \mathrm{ml}$ iced $\mathrm{H}_{2} \mathrm{O}$ and ${ }^{14} \mathrm{C}$-labeled glutamate separated by ion-exchange chromatography (30). The results were corrected for the blank value found in the absence of islets and corrected for the recovery of standards of $\mathrm{D}$ $(-)-\beta$-OHB prepared in the same incubation medium and treated throughout in the same manner. 
For measuring the activity of $\beta$-hydroxybutyrate dehydrogenase, groups of 500 islets were sonicated $(3 \times 10$ $\mathrm{s})$ in $0.6 \mathrm{ml}$ Tris. $\mathrm{HCl}$ buffer $(50 \mathrm{mM}$; $\mathrm{pH}$ 7.4). Aliquots $(30 \mu \mathrm{l})$ of the homogenate were mixed with $20 \mu \mathrm{l}$ of the same buffer containing increasing concentrations of $\mathrm{D}$ $(-)-\beta-\mathrm{OHB}$ and $50 \mu \mathrm{l}$ of a reaction mixture (18) consisting of the same buffer enriched with 1.0 mM EDTA, 2.0 $\mathrm{mM}$ L-cysteine, $0.25 \mathrm{mM}$ rotenone, $2.0 \mathrm{mM} \mathrm{NAD}^{+}$, and bovine serum albumin $(0.1 \mathrm{mg} / \mathrm{ml})$. After 10 to $30 \mathrm{~min}$ incubation at $20^{\circ} \mathrm{C}$, the reaction was halted by heating for 10 min at $80^{\circ} \mathrm{C}$. The NADH formed and the standards of $\mathrm{NADH}(2-8 \mathrm{nmol} / \mathrm{sample})$ were then measured as described above through the generation of $\mathrm{L}-\left[\mathrm{U}-{ }^{14} \mathrm{C}\right]-$ glutamate from 2 -[U- $\left.{ }^{14} \mathrm{C}\right]$ ketoglutarate. The generation of NADH was constant with time (10-30 min incubation) and proportional to the number of islets (5-25 islets/ sample).

All results are expressed as means $\pm \mathrm{SE}$ together with the number of individual determinations $(n)$ or degrees of freedom (df). The SE on the sum, difference, or ratio between mean values was calculated as described elsewhere $(39,41)$. The statistical significance of differences between mean values was assessed with Student's $t$ test.

\section{RESULTS}

Uptake and oxidation of ketone bodies. During 10-min incubation and after correction for extracellular contamination, as judged from the space of distribution of L-[1${ }^{14} \mathrm{C}$ ]glucose $(2.0 \mathrm{mM})$ measured in paired groups of islets, the net uptake of $\mathrm{D}-(-)-\beta-\left[3-{ }^{14} \mathrm{C}\right] \mathrm{OHB}$ and $\left[3-{ }^{14} \mathrm{C}\right] \mathrm{AcAc}$ $(10.0 \mathrm{mM}$ each) amounted to $12.8 \pm 4.2$ and $10.4 \pm 4.4$ pmol/islet, respectively ( $n=16$ and 17). Considering the intracellular space of the islets $(12,13)$, this suggests that the concentration of ketone bodies was close to reaching equilibrium across the islet cell plasma membrane.

In the absence of $\mathrm{D}$-glucose, the oxidation of $\mathrm{D}-(-)-\beta-$ $\left[3{ }^{14} \mathrm{C}\right] \mathrm{OHB}(10 \mathrm{mM})$ averaged $17.1 \pm 1.6 \mathrm{pmol} \cdot 120$ $\min ^{-1} \cdot$ islet $^{-1}$. Assuming full oxidation of the ketone body, the yield of $\mathrm{CO}_{2}$ represented only $58.2 \pm 6.2 \%$ of that recorded within the same experiments in the presence of $7.0 \mathrm{mM} \mathrm{D}-\left[\mathrm{U}-{ }^{14} \mathrm{C}\right]$ glucose (Table 1$)$. The hexose augmented markedly $(P<0.001) \mathrm{D}-(-)-\beta-\left[3-{ }^{14} \mathrm{C}\right] \mathrm{OHB}$ oxidation, which was concentration-related in the 2.5$10.0 \mathrm{mM}$ range. The association of $\mathrm{KCN}$ and antimycin A abolished $\mathbf{D}-(-)-\beta-\left[3{ }^{-14} \mathrm{C}\right] \mathrm{OHB}$ oxidation in either the absence or presence of $D$-glucose.

The oxidation of $\left[3-{ }^{14} \mathrm{C}\right] \mathrm{AcAc}$ was not significantly different in the absence or presence of $\mathrm{D}$-glucose, and also suppressed by $\mathrm{KCN}$ and antimycin $\mathrm{A}$. In the presence of $\mathrm{D}$-glucose $(7 \mathrm{mM})$, the oxidation of $\mathrm{D}-(-)-\beta-[3-$ $\left.{ }^{14} \mathrm{C}\right] \mathrm{OHB}$ and $\left[3-{ }^{14} \mathrm{C}\right] \mathrm{AcAc}$ (each $10 \mathrm{mM}$ ) occurred at similar rates. Neither $\mathrm{D}-(-)-\beta-\mathrm{OHB}$ nor AcAc (each 10 $\mathrm{mM})$ affected significantly the oxidation of $\mathrm{D}-\left[\mathrm{U}-{ }^{14} \mathrm{C}\right]$ glucose $(7 \mathrm{mM})$.

Activity of $\beta$-hydroxybutyrate dehydrogenase and interconversion of ketone bodies. In a series of seven experiments, the generation of $\mathrm{NADH}$ by islet homogenates incubated in the presence of $10 \mathrm{mM} \mathrm{D}-(-)-\beta$-OHB and $1.0 \mathrm{mM} \mathrm{NAD}{ }^{+}$averaged $1.19 \pm 0.27 \mathrm{pmol} \cdot \mathrm{min}^{-1} \cdot$ islet $^{-1}$. The $K_{\mathrm{m}}$ for D-(-)- $\beta$-OHB was close to $1.9 \mathrm{mM}$ (Fig. 1).

In the absence of $\mathrm{D}$-glucose, the production of $\left[{ }^{14} \mathrm{C}\right]$ AcAc from exogenous D- $(-)-\beta-\left[3-{ }^{14} \mathrm{C}\right] \mathrm{OHB}(10 \mathrm{mM})$ averaged $7.75 \pm 0.38 \mathrm{pmol} .120 \mathrm{~min}^{-1}$. islet ${ }^{-1}$ (Table 2). It was increased by $\sim 60 \%(P<0.001)$ in the presence of D-glucose $(7 \mathrm{mM})$. Whether in the presence or absence of the hexose, the generation of $\left[{ }^{14} \mathrm{C}\right] \mathrm{AcAc}$ was abolished by the combination of $\mathrm{KCN}(5 \mathrm{mM})$ and antimycin $\mathrm{A}$ $(0.01 \mathrm{mM})$, the reading recorded in the presence of these metabolic poisons not exceeding $0.83 \pm 1.51 \mathrm{pmol} \cdot 120$ $\min ^{-1} \cdot$ islet $^{-1}(n=8)$.

The comparison between the production of ${ }^{14} \mathrm{CO}_{2}$ and $\left[{ }^{14} \mathrm{C}\right] \mathrm{AcAc}$, respectively, by islets exposed to $\mathrm{D}-(-)-\beta-[3-$ ${ }^{14} \mathrm{C}$ ]OHB $(10 \mathrm{mM})$ in the absence of D-glucose, suggested that the oxidation of $\left[{ }^{14} \mathrm{C}\right] \mathrm{AcAc}$ accounted for $68.8 \pm$ $6.6 \%$ of its total generation rate. This contrasts with the situation previously documented in islets exposed to $\mathrm{L}$ leucine or 2-ketoisocaproate, in which case the major fraction of AcAc generated from the branched-chain amino or keto acid apparently escapes either oxidation or conversion of D-(-)- $\beta$-OHB $(16,22,31)$. For instance, in the presence of L-leucine $(10 \mathrm{mM})$, the comparison between the amino acid-induced increment in unlabeled AcAc production and the oxidation of $\mathrm{L}-\left[1-{ }^{14} \mathrm{C}\right]$ leucine suggests that $77.7 \pm 6.6 \%$ of the leucine-derived AcAc is not further metabolized (31). Similarly, in the present

TABLE 1. Reciprocal effects of ketone bodies and $D$-glucose on their respective oxidation

\begin{tabular}{|c|c|c|c|}
\hline $\begin{array}{c}{ }^{14} \mathrm{C} \text {-Labeled Nutrients, } \\
\mathrm{mM}\end{array}$ & $\begin{array}{l}\text { Unlabeled Agents, } \\
\mathrm{mM}\end{array}$ & $\begin{array}{c}\text { Oxidation Rate, } \\
\text { pmol.120 } \\
\mathrm{min}^{-1} \cdot \text { islet }^{-1}\end{array}$ & $n$ \\
\hline $10.0 \mathrm{D}-(-)-\beta-\left[3-{ }^{14} \mathrm{C}\right] \mathrm{OHB}$ & & $17.06 \pm 1.64$ & 55 \\
\hline $10.0 \mathrm{D}-(-)-\beta-\left[3-{ }^{14} \mathrm{C}\right] \mathrm{OHB}$ & $5 \mathrm{KCN}+0.01 \mathrm{AA}$ & $0.82 \pm 0.08$ & 4 \\
\hline $2.5 \mathrm{D}-(-)-\beta-\left[3-{ }^{14} \mathrm{C}\right] \mathrm{OHB}$ & 7.0 D-Glucose & $12.11+0.80$ & 24 \\
\hline $10.0 \mathrm{D}-(-)-\beta-\left[3-{ }^{14} \mathrm{C}\right] \mathrm{OHB}$ & $7.0 \mathrm{D}$-Glucose & $28.88 \pm 1.62$ & 32 \\
\hline $10.0 \mathrm{D}-(-)-\beta-\left[3-{ }^{14} \mathrm{C}\right] \mathrm{OHB}$ & 7.0 D-Glucose & & \\
\hline & $+5 \mathrm{KCN}+0.01 \mathrm{AA}$ & $0.17 \pm 0.07$ & 4 \\
\hline $10.0\left[3-^{14} \mathrm{C}\right] \mathrm{AcAc}$ & & $28.52 \pm 4.10$ & 27 \\
\hline $10.0\left[3-{ }^{14} \mathrm{C}\right] \mathrm{AcAc}$ & $5 \mathrm{KCN}+0.01 \mathrm{AA}$ & $-3.37 \pm 3.30$ & 16 \\
\hline $10.0\left[3{ }^{14} \mathrm{C}\right] \mathrm{AcAc}$ & $7.0 \mathrm{D}$-Glucose & $32.41 \pm 8.20$ & 18 \\
\hline $7.0 \mathrm{D}-\left[\mathrm{U}-{ }^{14} \mathrm{C}\right]$ glucose & & $19.54 \pm 0.90$ & 83 \\
\hline $7.0 \mathrm{D}-\left[\mathrm{U}-{ }^{14} \mathrm{C}\right]$ glucose & $10.0 \mathrm{D}-(-)-\beta-\mathrm{OHB}$ & $19.55 \pm 0.82$ & 14 \\
\hline $7.0 \mathrm{D}-\left[\mathrm{U}-{ }^{14} \mathrm{C}\right]$ glucose & $10.0 \mathrm{AcAc}$ & $18.39 \pm 0.96$ & 15 \\
\hline $16.7 \mathrm{D}-\left[\mathrm{U}-{ }^{14} \mathrm{C}\right]$ glucose & & $42.26 \pm 2.00$ & 9 \\
\hline
\end{tabular}

Values for oxidation rate are means $\pm \mathrm{SE} ; n$, no. of individual determinations. AA, antimycin A. 


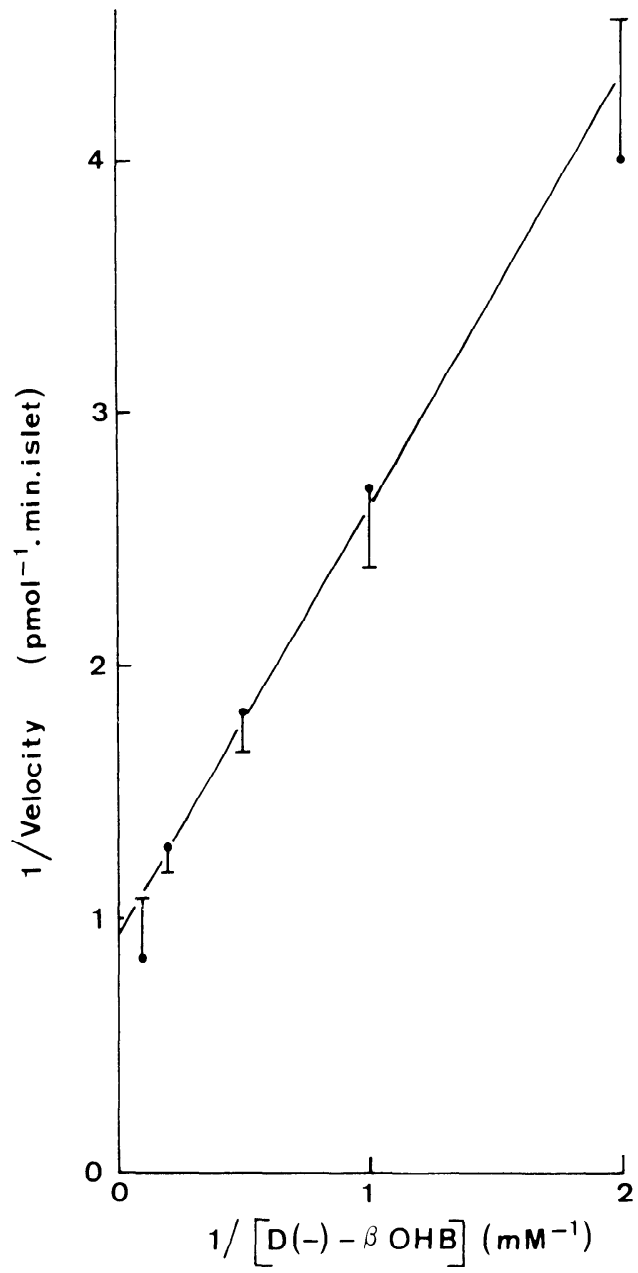

FIG. 1. Double reciprocal plot for activity of $\beta$-OHB dehydrogenase in islet homogenates. Values are means $\pm \mathrm{SE}$, derived from duplicate measurements collected in 4 separate experiments.

TABLE 2. Interconversion of ketone bodies in the absence or presence of D-glucose

\begin{tabular}{|c|c|c|c|c|c|c|}
\hline \multicolumn{3}{|c|}{ Exogenous Nutrient(s), mM } & \multicolumn{4}{|c|}{$\begin{array}{l}\text { Production, pmol } \cdot 120 \\
\min ^{-1} \cdot \text { islet }^{-1}\end{array}$} \\
\hline D-Glucose & $\begin{array}{c}\mathrm{D}-(-) \\
\beta-\left[3-^{-14} \mathrm{C}\right] \mathrm{OHB}\end{array}$ & AcAc & {$\left[{ }^{14} \mathrm{C}\right] \mathrm{AcAc}$} & $n$ & $\begin{array}{l}\mathrm{D}(-) \\
\beta-\mathrm{OHB}\end{array}$ & $n$ \\
\hline & 10.0 & & $7.75 \pm 0.38$ & 8 & $0.65 \pm 0.14$ & 20 \\
\hline & & 10.0 & & & $8.91 \pm 0.40$ & 20 \\
\hline $\begin{array}{l}7.0 \\
7.0\end{array}$ & 10.0 & & $3.22 \pm 0.56$ & 8 & $1.25 \pm 0.10$ & 14 \\
\hline 7.0 & & 10.0 & & & $11.74 \pm 0.51$ & 14 \\
\hline
\end{tabular}

Values for production means $\pm \mathrm{SE}$.

series of experiments, when both the generation of ${ }^{14} \mathrm{CO}_{2}$ and $\left[{ }^{14} \mathrm{C}\right] \mathrm{AcAc}$ were simultaneously measured in islets exposed to $\mathrm{L}-\left[\mathrm{U}-{ }^{14} \mathrm{C}\right]$ leucine $(10 \mathrm{mM})$, the results indicated that at least $71.7 \pm 8.8 \%(n=12)$ of the molecules of AcAc generated from exogenous L-leucine escaped further metabolism. To facilitate the interpretation of these contrasting behaviors, we examined the effects of $\mathbf{L}$-leucine and 2 -ketoisocaproate on the oxidation of $\mathbf{D}$ $(-)-\beta-\left[3-{ }^{14} \mathrm{C}\right] \mathrm{OHB}$. As shown in Table 3, the branchedchain amino or keto acid (each $10 \mathrm{mM}$ ) decreased by 30 $50 \%$ the generation of ${ }^{14} \mathrm{CO}_{2}$ from $\mathrm{D}-(-)-\beta-\left[3-{ }^{14} \mathrm{C}\right] \mathrm{OHB}$
TABLE 3. Reciprocal effect of $D-(-)-\beta-O H B$ and L-leucine on respective oxidation

\begin{tabular}{clrr}
\hline \hline $\begin{array}{c}{ }^{14} \mathrm{C}-\text { Labeled Nutrient, } \\
\mathrm{mM}\end{array}$ & $\begin{array}{c}\text { Unlabeled Agent(s), } \\
\mathrm{mM}\end{array}$ & $\begin{array}{c}\text { Oxidation Rate, } \\
\text { pmol.120 } \\
\mathrm{min}^{-1} \cdot \text { islet }^{-1}\end{array}$ & $n$ \\
\hline $10 \mathrm{D}-(-)-\beta-\left[3-{ }^{14} \mathrm{C}\right] \mathrm{OHB}$ & & $18.76 \pm 1.80$ & 27 \\
$10 \mathrm{D}-(-)-\beta-\left[3-{ }^{14} \mathrm{C}\right] \mathrm{OHB}$ & $10 \mathrm{~L}-$ Leucine & $12.83 \pm 0.94$ & 27 \\
$10 \mathrm{D}-(-)-\beta-\left[3-{ }^{14} \mathrm{C}\right] \mathrm{OHB}$ & 10 2-Ketoisocaproate & $9.21 \pm 1.16$ & 26 \\
& & $82.35 \pm 4.58$ & 16 \\
$10 \mathrm{~L}-\left[1-{ }^{14} \mathrm{C}\right]$ leucine & $10 \mathrm{D}-(-)-\beta-\mathrm{OHB}$ & $75.02 \pm 4.69$ & 9 \\
$10 \mathrm{~L}-\left[1-{ }^{14} \mathrm{C}\right]$ leucine & & & \\
$10 \mathrm{~L}-\left[\mathrm{U}-{ }^{14} \mathrm{C}\right]$ leucine & & $33.91 \pm 1.85$ & 15 \\
$10 \mathrm{~L}-\left[\mathrm{U}-{ }^{14} \mathrm{C}\right]$ leucine & $10 \mathrm{D}-(-)-\beta-\mathrm{OHB}$ & $32.37 \pm 1.29$ & 16 \\
$10 \mathrm{~L}-\left[\mathrm{U}-{ }^{14} \mathrm{C}\right]$ leucine & $5 \mathrm{KCN}+0.01 \mathrm{AA}$ & $0.45 \pm 0.20$ & 4 \\
\hline
\end{tabular}

Values for oxidation rate are means $\pm \mathrm{SE}$. AA, antimycin $\mathrm{A}$.

(also $10 \mathrm{mM}$ ). It should be underlined, however, that unlabeled $\mathbf{D}-(-)-\beta$-OHB failed to affect significantly the oxidation of either $\mathrm{L}-\left[1-{ }^{14} \mathrm{C}\right]$ leucine or $\mathrm{L}-\left[\mathrm{U}-{ }^{14} \mathrm{C}\right]$ leucine (Table 3). These findings indicate that, although the ketone body does not alter the catabolism of L-leucine, the oxidation of AcAc derived from exogenous $D-(-)-\beta-$ OHB is markedly inhibited in islets exposed to L-leucine or 2-ketoisocaproate. These results may reflect, in part at least, reciprocal isotopic dilution, e.g., of the acetylCoA pool.

The generation of $\mathrm{D}-(-)-\beta$-OHB from exogenous AcAc $(10 \mathrm{mM})$ amounted, in the absence of $\mathrm{D}$-glucose and after correction for the basal reading, to $8.26 \pm 0.42 \mathrm{pmol} \cdot 120$ $\mathrm{min}^{-1}$. islet ${ }^{-1}$ (Table 2). In the absence of exogenous AcAc, D-glucose $(7 \mathrm{mM})$ doubled $(P<0.005)$ the islet content and/or output of $\mathrm{D}-(-)-\beta$-OHB. The hexose, however, increased the AcAc-induced increment in D$(-)-\beta$-OHB production by only $27.0 \pm 8.8 \%$.

From the data summarized in Table 2, it can be calculated that, in terms of the net generation of NADH attributable to the interconversion of ketone bodies, the difference between islets exposed to $\mathrm{D}-(-)-\beta-\mathrm{OHB}$ and AcAc, respectively, amounts to $16.0 \pm 0.8$ pmol.120 $\mathrm{min}^{-1}$. islet ${ }^{1}$ in the absence of $\mathrm{D}$-glucose and $13.7 \pm 1.0$ $\mathrm{pmol} \cdot 120 \mathrm{~min}^{-1} \cdot$ islet $^{-1}$ in the presence of the hexose. These calculations are restricted to the fraction of the ketone bodies that escaped further oxidation. However, if the same calculation is applied to both unoxidized and oxidized ketone bodies, the difference in NADH generation at the level of the reaction catalyzed by $\beta$-hydroxybutyrate dehydrogenase would amount to $33.1 \pm 1.1$ and $42.6 \pm 1.0 \mathrm{pmol} \cdot 120 \mathrm{~min}^{-1}$. islet ${ }^{-1}$, in the absence and presence of $\mathrm{D}$-glucose, respectively.

Catabolism of endogenous nutrients and $\mathrm{O}_{2}$ uptake. To investigate the possible interference of ketone bodies with the catabolism of endogenous nutrients, we examined the effects of $\mathrm{D}-(-)-\beta-\mathrm{OHB}$ and AcAc on the production of ${ }^{14} \mathrm{CO}_{2}$ by islets prelabeled with either $\mathrm{L}-\left[\mathrm{U}-{ }^{14} \mathrm{C}\right]$ glutamine or $\left[\mathrm{U}_{-}{ }^{14} \mathrm{C}\right]$ palmitate, the oxidation of the latter two nutrients accounting for a major fraction of the basal respiration by islets deprived of exogenous nutrient $(20,30)$.

When islets were preincubated for $30 \mathrm{~min}$ with L-[U${ }^{14} \mathrm{C}$ ]glutamine $(1.0 \mathrm{mM})$, the radioactive content of the islets averaged $13.5 \pm 0.5 \mathrm{pmol}$ of glutamine-equivalent per islet (Table 4). After correction for the readings 
TABLE 4. Effect of ketone bodies and D-glucose on oxidation of endogenous nutrients

\begin{tabular}{|c|c|c|c|c|}
\hline & $\begin{array}{c}\mathrm{L}-\left[\mathrm{U}-{ }^{14} \mathrm{C}\right] \text { glutamine } \\
(1.0 \mathrm{mM})\end{array}$ & $n$ & $\begin{array}{l}{\left[\mathrm{U}-{ }^{14} \mathrm{C}\right] \text { palmitate }} \\
\quad(0.3 \mathrm{mM})\end{array}$ & $n$ \\
\hline $\begin{array}{l}\text { Net uptake of }{ }^{14} \mathrm{C} \text {-labeled } \\
\text { nutrients, } \mathrm{pmol} / \text { islet }^{\mathrm{c}}\end{array}$ & $13.53 \pm 0.54$ & 106 & $1.73 \pm 0.08$ & 140 \\
\hline \multicolumn{5}{|l|}{${ }^{14} \mathrm{CO}_{2}$ output, \%content } \\
\hline Control $^{\mathrm{d}}$ & $15.93 \pm 0.80$ & 24 & $6.93 \pm 0.62$ & 30 \\
\hline Metabolic poisons $^{\mathrm{e}}$ & $0.86 \pm 0.07$ & 14 & $0.19 \pm 0.04$ & 17 \\
\hline \multicolumn{5}{|l|}{$\begin{array}{l}\text { Effect of exogenous } \\
\text { nutrient(s) on }{ }^{14} \mathrm{CO}_{2} \\
\text { output, \% control }{ }^{\mathrm{f}}\end{array}$} \\
\hline No exogenous nutrient & $100.0 \pm 5.0$ & 23 & $100.0 \pm 7.3$ & 30 \\
\hline $10 \mathrm{D}-(-)-\beta-\mathrm{OHB}$ & $96.2 \pm 6.9$ & 12 & $71.1 \pm 4.8$ & 18 \\
\hline $10 \mathrm{AcAc}$ & $110.7 \pm 7.5$ & 11 & $71.8 \pm 6.0$ & 12 \\
\hline 7 D-Glucose & $123.2 \pm 5.9$ & 23 & $83.3 \pm 7.9$ & 32 \\
\hline $\begin{array}{l}7 \mathrm{D} \text {-Glucose }+10 \mathrm{D}-(-)- \\
\beta \text {-OHB }\end{array}$ & $137.8 \pm 8.5$ & 12 & $63.3 \pm 4.8$ & 18 \\
\hline 7 D-Glucose $+10 \mathrm{AcAc}$ & $132.1 \pm 9.4$ & 11 & $68.6 \pm 7.8$ & 13 \\
\hline
\end{tabular}

Values are means $\pm \mathrm{SE} .{ }^{\text {a }}$ Islets were preincubated for $30 \mathrm{~min}$ with $1.0 \mathrm{mM} \mathrm{L}-\left[\mathrm{U}-{ }^{14} \mathrm{C}\right]$ glutamine, then incubated for $30 \mathrm{~min}$ in absence or presence of unlabeled exogenous nutrient $(\mathrm{s}) .{ }^{\mathrm{b}}$ Islets were preincubated for $120 \mathrm{~min}$ with $0.3 \mathrm{mM}\left[\mathrm{U}_{-}{ }^{14} \mathrm{C}\right]$ palmitate in presence of $8.3 \mathrm{mM}$ Dglucose, then incubated for $120 \mathrm{~min}$ in absence or presence of unlabeled exogenous nutrient(s). ${ }^{\mathrm{c}}$ Net uptake of ${ }^{14} \mathrm{C}$-labeled nutrients was calculated at the onset of the final incubation. ${ }^{\mathrm{d}}$ Control value for output of ${ }^{14} \mathrm{CO}_{2}$ during final incubation performed in absence of exogenous nutrient was already corrected for readings recorded in presence of metabolic poisons. ${ }^{e}$ Metabolic poisons included $5.0 \mathrm{mM} \mathrm{KCN}, 0.01$ $\mathrm{mM}$ antimycin $\mathrm{A}$, and $0.01 \mathrm{mM}$ rotenone. ${ }^{\mathrm{f}}$ All readings were corrected for ${ }^{14} \mathrm{CO}_{2}$ output recorded in presence of metabolic poisons.

collected in the presence of metabolic poisons $(\mathrm{KCN}$, antimycin $\mathrm{A}$, and rotenone), the output of ${ }^{14} \mathrm{CO}_{2}$ during a further incubation of $30 \mathrm{~min}$ performed in the absence of any exogenous nutrient represented $15.9 \pm 0.8 \%$ of the islet radioactive content. Neither $\mathrm{D}-(-)-\beta-\mathrm{OHB}$ nor AcAc (each $10 \mathrm{mM}$ ) significantly affected the ${ }^{14} \mathrm{CO}_{2}$ output during the final incubation, whether in the absence or presence of $\mathrm{D}$-glucose $(7 \mathrm{mM})$. The hexose, however, significantly increased the production of ${ }^{14} \mathrm{CO}_{2}$ $(P<0.005)$. For reasons discussed elsewhere $(20)$, this effect of D-glucose does not coincide with any sizable change in $\mathrm{O}_{2}$ uptake attributable to the catabolism of endogenous amino acids.

When islets were preincubated for $120 \mathrm{~min}$ with [U${ }^{14} \mathrm{C}$ ]palmitate $(0.3 \mathrm{mM})$ in the presence of D-glucose $(8.3$ $\mathrm{mM}$ ), the radioactive content of the islets amounted to $1.73 \pm 0.08 \mathrm{pmol}$ of palmitate-equivalent per islet (Table 4). After correction for the readings recorded in the presence of metabolic poisons, the ouput of ${ }^{14} \mathrm{CO}_{2}$ during a further incubation of $120 \mathrm{~min}$ conducted in the absence of exogenous nutrient represented $6.91 \pm 0.62 \%$ of the initial radioactive content of the islets. Relative to such a control value, D-(-)- $\beta$-OHB and AcAc (10 mM each) inhibited ${ }^{14} \mathrm{CO}_{2}$ output by $28-29 \%(P<0.025)$. D-Glucose $(7 \mathrm{mM})$ failed to significantly affect $(P>0.1)$ the output of ${ }^{14} \mathrm{CO}_{2}$, which was decreased by $31-34 \%(P<0.02)$ in the concomitant presence of the hexose and ketone bodies (Table 4). Incidentally, when islets were immediately exposed for $120 \mathrm{~min}$ to $\left[\mathrm{U}-{ }^{14} \mathrm{C}\right.$ ]palmitate $(0.1 \mathrm{mM})$ in the presence of D-glucose $(7 \mathrm{mM})$, the oxidation of the fatty acid $\left(0.28 \pm 0.03 \mathrm{pmol} .120 \mathrm{~min}^{-1} \cdot\right.$ islet $\left.^{-1} ; n=7\right)$ failed to be affected by $\mathrm{D}-(-)-\beta$-OHB ( $10 \mathrm{mM}$; data not shown), suggesting that the sparing action of ketone bodies on
${ }^{14} \mathrm{CO}_{2}$ output from islets prelabeled with $\left[\mathrm{U}_{-}{ }^{14} \mathrm{C}\right]$ palmitate may be due, to a large extent, to inhibition of lipolysis. This proposal is consistent with both the large esterification of $\left[\mathrm{U}-{ }^{14} \mathrm{C}\right]$ palmitate during the preincubation period (38) and the well-known antilipolytic effects of ketone bodies in other cell types $(1,5,10)$.

Taken as a whole, the findings summarized in Table 4 suggest that ketone bodies fail to affect the catabolism of endogenous glutamate (derived from $\mathrm{L}-\left[\mathrm{U}-{ }^{14} \mathrm{C}\right]$ glutamine), but exert a significant sparing action on the catabolism of endogenous fatty acids. Hence, the latter effect was taken into account to assess the overall effect of ketone bodies on $\mathrm{O}_{2}$ consumption by the islets (Table $5)$.

The effect of ketone bodies on islet respiration was also explored through the direct measurement of $\mathrm{O}_{2}$ uptake by polarography. The basal rate of $\mathrm{O}_{2}$ uptake averaged $4.16 \pm 0.56 \mathrm{pmol} \cdot \mathrm{min}^{-1} \cdot$ islet $^{-1}(n=13)$. As shown in Fig. 2, the administration of D-glucose $(7 \mathrm{mM})$ to islets first deprived of exogenous nutrient increased $\mathrm{O}_{2}$ consumption by $57.3 \pm 11.4 \%(n=10 ; P<0.001)$. Similarly, when the islets were first exposed to either D$(-)-\beta-\mathrm{OHB}$ or AcAc (10 $\mathrm{mM}$ each), the addition of Dglucose $(7 \mathrm{mM})$ provoked an increase in $\mathrm{O}_{2}$ uptake that represented $60.4 \pm 16.0 \%(n=10 ; P<0.005)$ of the paired basal respiration. In the absence of D-glucose, D(-)- $\beta$-OHB and AcAc (each $10 \mathrm{mM}$ ) increased $\mathrm{O}_{2}$ uptake by $19.1 \pm 4.1 \%(n=6 ; P<0.005)$ and $25.4 \pm 3.9 \%(n=$ $4 ; P<0.01$ ), respectively (Fig. 2). When the islets were first exposed to D-glucose $(7 \mathrm{mM})$, the administration of AcAc $(10 \mathrm{mM})$ failed to cause any sizable change in respiration $(n=6 ; P>0.1)$, whereas $\mathrm{D}-(-)-\beta$-OHB further augmented by $15.0 \pm 4.6 \%(n=8 ; P<0.02)$ the glucose-induced paired increase in $\mathrm{O}_{2}$ consumption. As shown in Fig. $2 A$, there was a fair correlation $(r=0.922$; $P<0.01$ ) between the observed changes in respiration and the theoretical values derived from both the interconversion of ketone bodies and oxidative data on the fate of exogenous and endogenous ${ }^{14} \mathrm{C}$-labeled nutrients (Table 5).

ATP generation and insulin release. When the rate of insulin release was compared with either the experimental or calculated changes in $\mathrm{O}_{2}$ uptake, a typical relationship (Fig. $2 B$ ) characterized by a threshold value for the stimulation of insulin release as a function of islet respiration $(15,30)$ was observed. In considering this relationship, it should be realized that the respiratory data do not fully inform on the high-energy yield because of differences in the $\mathrm{P} / \mathrm{O}$ ratio for the oxidation of distinct nutrients. For instance, the extramitochondrial net generation of ATP associated with anaerobic glycolysis does not lead to a change in $\mathrm{O}_{2}$ uptake. Similarly, the conversion of AcAc to acetoacetyl CoA in the reaction catalyzed by acetoacetate-succinate CoA-transferase occurs at the expense of guanosine $5^{\prime}$-triphosphate (GTP) that would otherwise be formed through the succinyl-CoA synthetase reaction in the citric acid cycle (33). Because the generation of ATP, or more precisely the cytosolic ATPto-ADP ratio, is currently thought to control the closing of ATP-responsive $\mathrm{K}^{+}$channels located at the B-cell plasma membrane $(28,35)$, the next series of experiments 
TABLE 5. Changes in $\mathrm{O}_{2}$ uptake calculated from fate of ${ }^{14} \mathrm{C}$-labeled nutrient(s)

\begin{tabular}{|c|c|c|c|c|c|}
\hline & \multicolumn{5}{|c|}{ Nutrients, mM } \\
\hline & $10 \mathrm{D}-(-)-\beta-\mathrm{OHB}$ & $10 \mathrm{AcAc}$ & $7 \mathrm{D}$-Glucose & $\begin{array}{rl}7 & \mathrm{D}-\text { Glucose } \\
+10 \mathrm{D}-(-)-\beta-\mathrm{OHB}\end{array}$ & $\begin{array}{l}7 \text { D-Glucose } \\
+10 \mathrm{AcAc}\end{array}$ \\
\hline Oxidation of exogenous nutrient(s) & $+76.8 \pm 7.4$ & $+114.1 \pm 16.4$ & $+117.2 \pm 5.4$ & $+247.3 \pm 8.8$ & $+240.0 \pm 33.3$ \\
\hline Oxidation of endogenous nutrients & $-57.8 \pm 9.6$ & $-56.4 \pm 12.0$ & $-33.4 \pm 15.8$ & $-67.4 \pm 9.6$ & $-62.8 \pm 15.6$ \\
\hline Interconversion of ketone bodies & $+3.9 \pm 0.2$ & $-4.3 \pm 0.2$ & 0 & $+1.6 \pm 0.3$ & $-5.2 \pm 0.3$ \\
\hline Calculated change in $\mathrm{O}_{2}$ uptake & $+22.9 \pm 12.1$ & $+53.4 \pm 20.3$ & $+83.8 \pm 16.7$ & $+181.5 \pm 13.0$ & $+172.0 \pm 36.8$ \\
\hline
\end{tabular}

Values are means $\pm \mathrm{SE}$ in pmol $\mathrm{O}_{2} \cdot 120 \mathrm{~min}^{-1} \cdot$ islet $^{-1}$. We converted sparing action of exogenous nutrient(s) on ${ }^{14} \mathrm{CO}_{2}$ output from islets prelabeled with $\left[\mathrm{U}^{14} \mathrm{C}\right]$ palmitate to a respiratory rate, assuming that endogenous fatty acids account for $40 \%$ of basal $\mathrm{O}_{2}$ uptake (see Ref. 30 ).
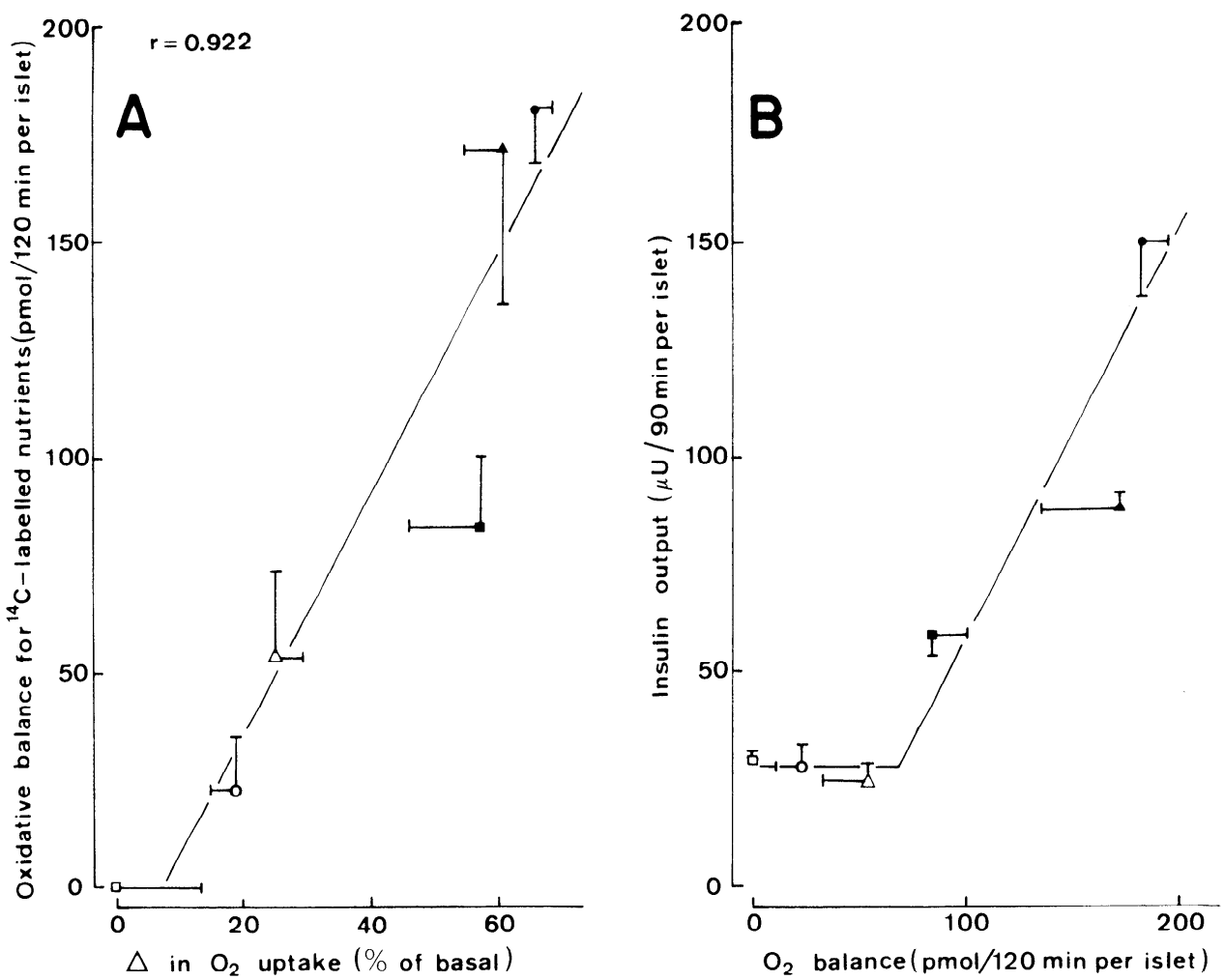

FIG. 2. $A$ : correlation between observed changes in $\mathrm{O}_{2}$ uptake and oxidative data collected with ${ }^{14} \mathrm{C}$-labeled nutrients (Table 5) in islets incubated in absence (squares) or presence of either D-(-)- $\beta$ hydroxybutyrate (circles) or acetoacetate (triangles) tested at a concentration of 10 $\mathrm{mM}$ with (closed symbols) or without (open symbols) D-glucose $(7 \mathrm{mM}) . B$ : relationship between insulin release and oxidative data (same presentation as in $A$ ).

aimed at investigating the effect of ketone bodies on ${ }^{86} \mathrm{Rb}$ outflow from prelabeled islets.

${ }^{86} \mathrm{Rb}$ outflow. The effect of ketone bodies on ${ }^{86} \mathrm{Rb}$ outflow was examined both in the absence and presence of D-glucose $(7 \mathrm{mM})$.

In the absence of the hexose, the increase in $\mathrm{O}_{2}$ uptake evoked by $\mathrm{D}-(-)-\beta$-OHB $(10 \mathrm{mM})$ coincided with a modest but significant decrease in both ${ }^{86} \mathrm{Rb}$ and ${ }^{45} \mathrm{Ca}$ fractional outflow rate and a paradoxical early decrease in insulin output (Fig. 3). As judged from the changes in either effluent radioactivity or insulin output recorded just before ( $\min 40$ vs. 44 ) and after ( $\min 44$ vs. 48) introduction of $\mathrm{D}-(-)-\beta-\mathrm{OHB}$, the inhibitory action of the ketone body on cationic fluxes and hormonal secretion was highly significant in all cases $(P<0.001)$. The fall in ${ }^{86} \mathrm{Rb}$ outflow, which was observed in 12 separate experiments, was reminiscent of, but less pronounced than, that evoked by D-glucose when tested at concentrations below that required for stimulation of insulin release (7). Hence, it could result from a modest increase in cytosolic ATP-to-ADP ratio (28) and/or the partial inactivation of a $\mathrm{Ca}^{2+}$-dependent modality of $\mathrm{K}^{+}$outflow $(11,25)$. The latter hypothesis takes into account the fact that $\mathrm{D}-(-)-\beta$-OHB caused an early decrease in basal insulin output, suggesting that the ketone body may lower cytosolic $\mathrm{Ca}^{2+}$ activity. Because $\mathrm{D}-(-)-\beta-\mathrm{OHB}$ also inhibited ${ }^{45} \mathrm{Ca}$ outflow from the islets perifused in the absence of $\mathrm{D}$-glucose but presence of extracellular $\mathrm{Ca}^{2+}$, the postulated lowering of cytosolic $\mathrm{Ca}^{2+}$ concentration could conceivably result from stimulation of $\mathrm{Ca}^{2+}$ uptake by intracellular organelles (14).

In the presence of $\mathrm{D}$-glucose $(7 \mathrm{mM})$, both $\mathrm{D}-(-)-\beta$ $\mathrm{OHB}$ and AcAc (10 $\mathrm{mM})$ provoked a rapid and rapidly reversible inhibition of ${ }^{86} \mathrm{Rb}$ outflow (Fig. 4). At normal extracellular $\mathrm{Ca}^{2+}$ concentration $(1.0 \mathrm{mM})$, the initial fall in effluent radioactivity was followed, after 5- to 6-min exposure to the ketone bodies by a modest but systematic reascension in ${ }^{86} \mathrm{Rb}$ outflow. As shown in Fig. $4 B$, such a phenomenon failed to occur when the experiments were repeated in the absence of extracellular $\mathrm{CaCl}_{2}$ and presence of ethylene glycol-bis( $\beta$-aminoethyl ether)$N, N, N^{\prime}, N^{\prime}$-tetraacetic acid (EGTA) (0.5 mM). Thus, between the 60th and 68th min of perifusion (i.e., after 16-min exposure to AcAc), the ${ }^{86} \mathrm{Rb}$ fractional outflow rate was significantly lower $(P<0.05)$ in the absence than in the presence of extracellular $\mathrm{Ca}^{2+}$, although such 

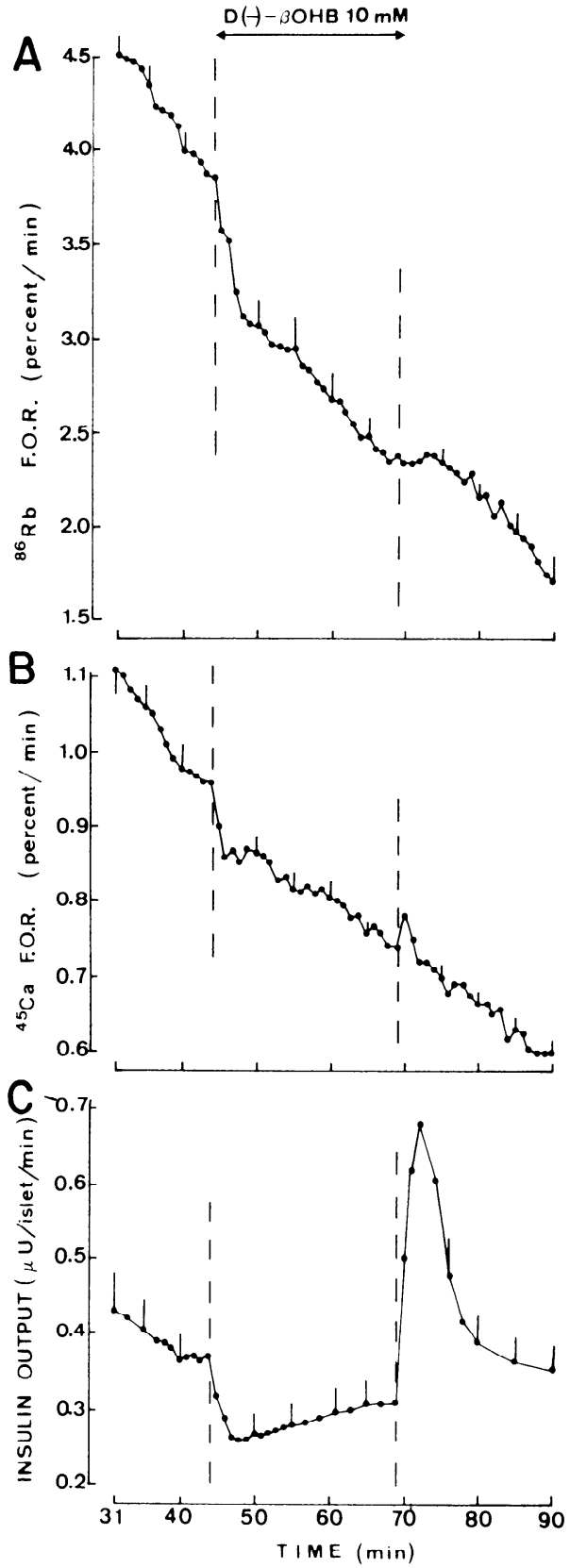

FIG. 3. Effect of $\mathrm{D}-(-)-\beta$-hydroxybutyrate $[\mathrm{D}-(-)-\beta-\mathrm{OHB}](10 \mathrm{mM})$ on ${ }^{86} \mathrm{Rb}$ fractional outflow rate (FOR; $A$ ) ${ }^{45} \mathrm{Ca}$ fractional outflow rate $(B)$, and insulin release $(C)$ from islets perifused throughout in absence of glucose at normal $\mathrm{Ca}^{2+}$ concentration $(1.0 \mathrm{mM})$. Values (means \pm $\mathrm{SE})$ refer to 8-9 individual experiments.

was not the case before administration of the ketone body. These findings are compatible with the view that the secondary reascension in ${ }^{86} \mathrm{Rb}$ outflow reflects a $\mathrm{Ca}^{2+}$. dependent activation of $\mathrm{K}^{+}$channels.

Mitochondrial redox state and oxidation of $D-\left[6-{ }^{14} \mathrm{C}\right]$ glucose. Our measurements concerning the generation of both $\mathrm{D}-(-)-\beta$-OHB from unlabeled exogenous AcAc and $\left[{ }^{14} \mathrm{C}\right] \mathrm{AcAc}$ from exogenous $\mathrm{D}-(-)-\beta-\left[3-{ }^{14} \mathrm{C}\right] \mathrm{OHB}$ refer to the islet content and output of each metabolite. They do not inform therefore on the mitochondrial NADH-to$\mathrm{NAD}^{+}$ratio (42). The interconversion of ketone bodies could conceivably affect the latter ratio. It was recently proposed $(21,27)$ that the mitochondrial accumulation of $\mathrm{Ca}^{2+}$, as ruled inter alia by the mitochondrial redox state (19), plays a critical role in regulating the activity of key mitochondrial dehydrogenases (e.g., pyruvate dehydrogenase, isocitrate dehydrogenase, and 2-ketoglutarate dehydrogenase) in islet cells. The effect of ketone bodies on the generation of ${ }^{14} \mathrm{CO}_{2}$ from $\mathrm{D}-\left[6-{ }^{14} \mathrm{C}\right]$ glucose was assessed, therefore, to investigate specifically the oxidation in the tricarboxylic acid cycle of acetyl residues derived from exogenous D-glucose. Exogenous AcAc (10 $\mathrm{mM})$ decreased $(P<0.025)$ and exogenous $\mathrm{D}-(-)-\beta$-OHB (also $10 \mathrm{mM})$ increased $(P<0.02) \mathrm{D}-\left[6{ }^{-14} \mathrm{C}\right]$ glucose oxidation from a control value of $17.1 \pm 0.7$ to, respectively, $14.2 \pm 1.0$ and $20.8 \pm 1.3 \mathrm{pmol} \cdot 120 \mathrm{~min}^{-1} \cdot$ islet $^{-1}(n=$ $15-16$ in all cases).

\section{DISCUSSION}

The present data indicate that ketone bodies penetrate into islet cells, undergo interconversion in the reaction catalyzed by $\beta$-hydroxybutyrate dehydrogenase, and are converted to $\mathrm{CO}_{2}(2)$, the latter two processes presumably taking place in mitochondria. The extent of AcAc oxidation, relative to its availability or generation rate, appears markedly affected by environmental factors such as the presence of $\mathrm{D}$-glucose or L-leucine. Thus, whereas L-leucine decreases the oxidation of $\mathrm{D}-(-)-\beta-\left[3-{ }^{14} \mathrm{C}\right]-$ $\mathrm{OHB}, \mathrm{D}$-glucose exerts an opposite and stimulatory effect on ${ }^{14} \mathrm{CO}_{2}$ output by islets exposed to $\mathrm{D}-(-)-\beta-\left[3-{ }^{14} \mathrm{C}\right]-$ OHB. The latter stimulation was already observed in several other cell types $(17,34)$, but we are not aware of any documented explanation for such a phenomenon.

The close correlation observed in the present study between the rates of $\mathrm{O}_{2}$ uptake and insulin release by the islets strongly suggests that the insulinotropic action of ketone bodies is causally related to their catabolism, possibly through changes in ATP generation rate.

As already noted in a prior study (4), there was no tight relationship between the oxidation of ${ }^{14} \mathrm{C}$-labeled exogenous nutrients, tested alone or in combination and the corresponding secretory data. However, such an observation is not sufficient to deny the cause-to-effect link between the catabolism of these nutrients and their insulinotropic action. Indeed, allowance must also be made for both the reciprocal effects of exogenous nutrients on their respective metabolic fate and their sparing action on the utilization of endogenous nutrients in the islet cells. Moreover, the secretory response to ketone bodies may also depend on the relative extent of their interconversion in the reaction catalyzed by $\beta$-hydroxybutyrate dehydrogenase (3).

In these respects, the situation found in the present study is similar to that previously documented when the effect of pyruvate and lactate on the net generation of reducing equivalents in islets $(24,38)$ is considered. These two situations differ, however, from one another by the subcellular location of the relevant dehydrogenase. It is likely that the interconversion of ketone bodies affects primarily the mitochondrial rather than cytosolic redox state. It was recently proposed that the mitochondrial redox state may, through modulating the calcium content of mitochondria (19), control the activity of mitochondrial enzymes such as glycerol phosphate de- 

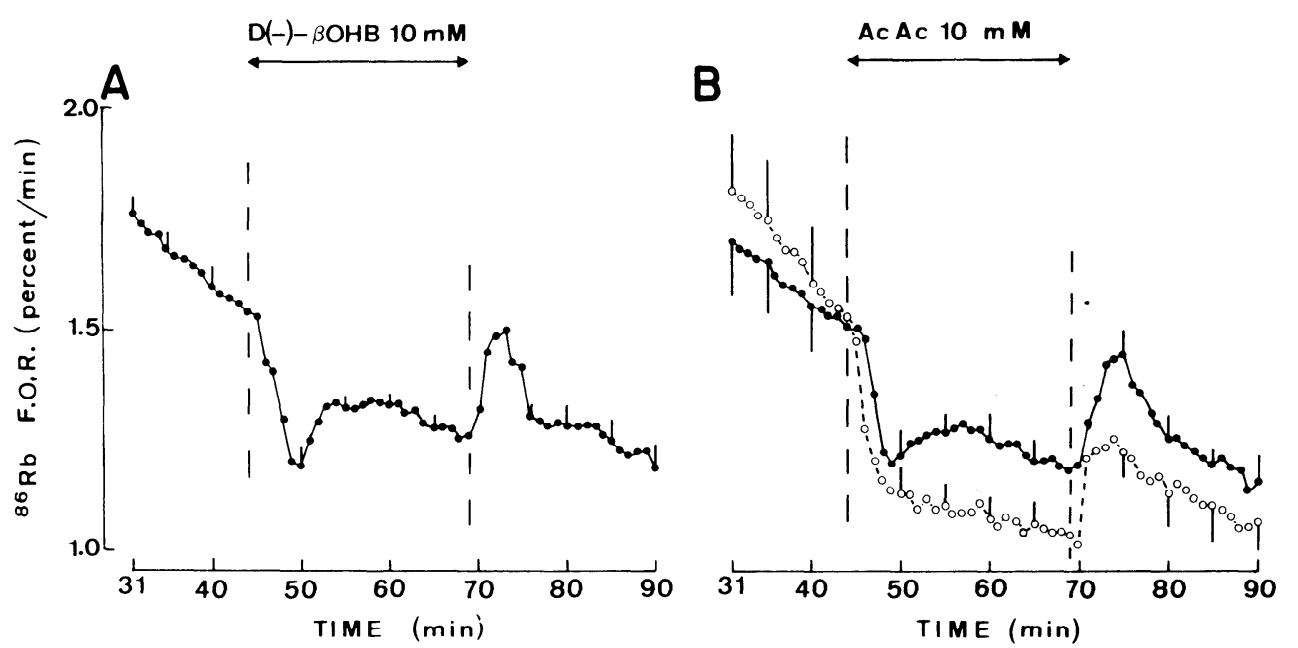

FIG. 4. Effect of $\mathrm{D}-(-)-\beta$-hydroxybu tyrate [D-(-)- $\beta$-OHB; $10 \mathrm{mM} ; A]$ or AcAc $(10 \mathrm{mM} ; B)$ on ${ }^{86} \mathrm{Rb}$ FOR from islets perifused throughout in presence of $7 \mathrm{mM}$ D-glucose. Basal media either contained $1.0 \mathrm{mM} \mathrm{Ca}{ }^{2+}$ (closed circles and solid line) or were deprived of $\mathrm{Ca}^{2+}$ and enriched with $0.5 \mathrm{mM}$ FGTA (open circles and dashed line). Values (means $\pm \mathrm{SE}$ ) refer to 4-6 individual experiments. hydrogenase, isocitrate dehydrogenase, and 2-ketoglutarate dehydrogenase $(21,27)$. The modest but significant changes in $\mathrm{D}-\left[6-{ }^{14} \mathrm{C}\right]$ glucose oxidation evoked by either D-(-)- $\beta-\mathrm{OHB}$ or AcAc affords further support to such a proposal.

A further argument in support of a cause-to-effect link between the metabolic and secretory response to ketone bodies consists in the finding that these nutrients inhibit ${ }^{86} \mathrm{Rb}$ outflow from prelabeled islets. In the process of nutrient-stimulated insulin release, the closing of ATPresponsive $\mathrm{K}^{+}$channels, as induced by a rise in the cytosolic ATP-to-ADP ratio, is currently thought to play an essential role in coupling the catabolism of nutrient secretagogues to the depolarization of the plasma membrane and further gating of voltage-sensitive $\mathrm{Ca}^{2+}$ channels $(28,35)$. The resulting increase in cytosolic $\mathrm{Ca}^{2+}$ activity may then not solely trigger insulin release but also favor the exit of $\mathrm{K}^{+}$from the islet cells through $\mathrm{Ca}^{2+}$-responsive channels $(11,25)$. The present data indeed suggest that the changes in ${ }^{86} \mathrm{Rb}$ outflow evoked by ketone bodies in the presence of $\mathrm{D}$-glucose involve both a $\mathrm{Ca}^{2+}$-independent decrease and a $\mathrm{Ca}^{2+}$-dependent increase in $\mathrm{K}^{+}$conductance.

The cationic and secretory data collected in perifused islets exposed to $\mathrm{D}-(-)-\beta-\mathrm{OHB}$ in the absence of $\mathrm{D}$ glucose suggest that the ketone body may lower cytosolic $\mathrm{Ca}^{2+}$ concentration by favoring the entry of the cation into intracellular organelles. Therefore, the increase in ${ }^{45} \mathrm{Ca}$ net uptake evoked by $\mathrm{D}-(-)-\beta$-OHB in islets first exposed to ${ }^{45} \mathrm{Ca}$ in the absence of $\mathrm{D}$-glucose and then submitted at low temperature to extensive washes to remove extracellular radioactivity (26) could correspond, in part at least, to an intracellular redistribution of the tracer cation. The fact that, under the same experimental conditions, AcAc failed to significantly affect ${ }^{45} \mathrm{Ca}$ net uptake, would then again point to the changes in mitochondrial redox state as a regulatory factor in the control of mitochondrial calcium content.

Taken as a whole, these considerations merely emphasize the view that some caution should be exerted when considering the possible link between the metabolism of ketone bodies in islet cells and their insulinotropic action. In this respect, a further factor that could conceiv- ably participate in the stimulus-secretion coupling might consist in changes in intracellular $\mathrm{pH}$, as resulting for instance from the possible transport of undissociated $\beta$ hydroxybutyric or acetoacetic acid into the islet cells.

The changes in insulin release evoked by ketone bodies differ vastly as a function of the nature and concentration of other nutrients (e.g., L-leucine instead of Dglucose) concomitantly used to stimulate the B-cell (4). It should be duly underlined therefore that the present study was purposely restricted to the effect of ketone bodies in islets incubated in the absence or presence of D-glucose.

Within these limits, the comparison of oxidative, biosynthetic, cationic, and secretory data strongly suggests that the insulinotropic potential of ketone bodies is tightly and causally linked to their catabolism in islet cells. The present work extends therefore to ketone bodies the fuel concept (29) for the stimulation of insulin release by nutrient secretagogues.

We are grateful to M. Mahy, J. Schoonheydt, M. Urbain, and G. Vandenbroeck for technical assistance and C. Demesmaeker for secretarial help.

This study was supported by grants from the Belgian Foundation for Scientific Medical Research and Belgian Ministry of Scientific Policy and a predoctoral fellowship of the Belgian Institute for Scientific Research in Industry and Agriculture to J. Rasschaert.

Address for reprint requests: W. J. Malaisse, Laboratory of Experimental Medicine, Brussels Free University, 115 Blvd. de Waterloo, B1000 Brussels, Belgium.

Received 25 September 1989; accepted in final form 1 March 1990.

\section{REFERENCES}

1. Balasse, E. O., AND H. A. Ooms. Changes in the concentration of glucose, free fatty acids, insulin and ketone bodies in the blood during sodium $\beta$-hydroxybutyrate infusions in man. Diabetologia 4 : 133-135, 1968.

2. BERNE, C. The metabolism of lipids in mouse pancreatic islets. The oxidation of fatty acids and ketone bodies. Biochem. J. 152: 661-666, 1975.

3. BERnE, C. Determination of D-3-hydroxybutyrate dehydrogenase in mouse pancreatic islets with a photokinetic technique using bacterial luciferase. Enzyme 21: 127-136, 1976.

4. BIDEN, T. J., $\Lambda$ ND K. W. TAYLOR. Effects of ketone bodies on insulin release and islet-cell metabolism in the rat. Biochem. J. 212: 371-377, 1983.

5. BJörntorP, P., AND T. Schersten. Effect of $\beta$-hydroxybutyrate 
on lipid mobilization. Am. J. Physiol. 250: 683-687, 1967.

6. Blachier. F. A. Sener, and W. J. Malaisse. Interference of a nonmetabolized analogue of L-leucine with lipid metabolism in tumoral pancreatic islet cells. Biochim. Biophys. Acta 921: 494501.1987.

7. Carpinei.li, A. K., AND W. J. Malaisse. Regulation of ${ }^{86} \mathrm{Rb}$ nutflow from pancreatic islets: the dual effect of nutrient secretagogues. J. Physiol. Lond. 315: 143-156, 1981.

8. Carpinelt.i, A. R., AnD W. J. Malaisse. Regulation of ${ }^{86} \mathrm{Rh}^{+}$ efflux from pancreatic islets. I. Reciprocal changes in the response to glucose, tetraethylammonium and quinine. Mol. Cell. Endocrinol. 17: 103-110, 1980.

9. Carpinelli, A. R., A. Sener, A. Herchuelz, and W. J. MaLAISSE. The stimulus-secretion coupling of glucose-induced insulin release. XLI. Effect of intraccllular acidification on calcium efflux from islet cells. Metabolism 29: 540-545, 1980.

10. Ferry, F., and E. O. Balasse. Differential effects of sodium acetoacetate and acetoacetic acid infusions on alanine and glutamine metabolism in man. J. C'lin. Invest. 66: 323-331, 1980.

11. Findlay, I., M. J. Dunne, and O. H. Petersen. High-conductance $\mathrm{K}^{+}$channel in pancreatic islet cells can be activated and inactivated by internal calcium. J. Membr. Biol. 83: 169-175, 1985.

12. Girotx, M.-H., A. Sener, And W. J. Malaisse. Artefactual and true uptake of labeled sucrose by rat pancreatic islets. Comp. Biochem. Physiol. A Comp. Physiol. 85: 289-296, 1986.

13. Giroix, M.-H., A. Sener, D. G. Pipeleers, and W. J. Malaisse. Hexose metabolism in pancreatic islets. Inhibition of hexokinase. Biochem. J. 223: 447-453, 1984.

14. Hellman, B. $\beta$-Cell cytoplasmic $\mathrm{Ca}^{2+}$ balance as a determinant for glurnse stimulated insulin release. Diabetologia 28: 494 501, 1985 .

15. Hutton, J. C., and W. J. Malaisse. Dynamics of $\mathrm{O}_{2}$ consumption in rat pancreatic islets. Diabetologia 18: 394-405, 1980.

16. Hutton, J. C., A. SEner, and W. J. Malaisse. The metabolism of 4-methyl-2-oxopentanoate in rat pancreatic islets. Biochem. J. 184: 291-301, 1979.

17. Ide, T., J. Steinke, and G. F. Cahill, JR. Metabolic interactions of glurose, lactate, and $\beta$-hydroxybutyrate in rat brain slices. $\mathrm{Am}$. J. Physiol. 217: 784-792, 1969.

18. Krfis, H. A., D. H. Williamson, and H. Ü. Bergmeyer. 3Hydroxybutyrate dehydrogenase. In: Methods in Enzymology, edited by .J. M. Lowenstein. New York: Academic, 1969, vol. 14, p. $222-227$.

19. Ienninger, A. L., B. Reynafarje, A. Vercesi, and W. P. Tew. Transport and accumulation of calcium in mitochondria. Ann. NY Acad Sci. 307: 160-174, 1978.

20. Malaisse, W. J., L. Best, S. Kawazu, F. Malaisse-Lagae, and A. SFNFR. The stimulus-secretion coupling of glucose-induced insulin release: fuel metabolism in islets deprived of exogenous nutrient. Arch. Biochem. Biophys. 224: 102-110, 1983.

21. Malaisse, W. J., F. Blachier, R. Pochet, B. Manuel, Y. KFENOY, AND A. SENER. Calmodulin and calbindin in pancreatic islet cells. In: Calcium Binding Proteins in Normal and Transformed Cells, edited by D. E. M. Lawson and R. Pochet. New York: Plenum, 1989, p. 127-131.

22. Malaisse, W. J., J. C. Hutton, A. R. Carpinelli, A. HerCHUELZ, AND A. SENER. The stimulus-secretion coupling of amino acid-induced insulin release. Metabolism and cationic effects of leucine. Diabetes 29: 431-437, 1980.

23. Malaisse, W. J., J. C. Hutton, S. Kawazu, and A. Sener. The stimulus-secretion coupling of glucose-induced insulin release. Metabolic effects of menadione in isolated islets. Eur. J. Biochem. 87: 121-130, 1978 .

24. Malaisse. W. J., S. Kawazu, A. Herchuelz, J. C. Hutton, G.
Somers, G. Devis, AND A. Sener. The stimulus-secretion coupling of glucose-induced insulin releasc. XXXIV. Effect of lactate on islet function. Arch. Biochem. Biophys. 194: 49-62, 1979.

25. Malaisse, W. J., P. Lebrun, and A. Herchuelz. Ionic determinants of bioelectrical spiking activity in the pancreatic B-cell. Pfluegers Arch. 395: 201-203, 1982.

26. Malaisse, W. J., P. Lebrun, B. Yaylali, J. Camara, I. ValVERDE, AND A. SEnER. Ketone bodies and islet function: ${ }^{45} \mathrm{Ca}$ handling, insulin synthesis, and release. Am. J. Physiol. 259 (Endocrinol. Metab. 22): E117-E122, 1990.

27. Malaisse, W. J., F. Malaisse-Lagae, J. Rasschaert, D. Zähner, A. Sener, D. R. Davies, and E. Van Schaftingen. The fuel concept for insulin release: regulation of glucose phosphorylation in pancreatic islets. Biochem. Soc. Trans. 18: 107-108, 1990.

28. Malaisse, W. J., and $\Lambda$. Sener. Glucose-induced changes in cytosolic ATP content in pancreatic islets. Biochim. Biophys. Acto 927: 190-195, 1987.

29. Malaisse, W. J., A. Sener, A. Herchuelz, and J. C. IIutron. Insulin release: the fuel hypothesis. Metabolism 28: 373-386, 1979.

30. Malaisse, W. J., A. Sener, F. Malaisse-Lagae, J. C. Hutton, AND J. ChRistorhE. The stimulus-secretion coupling of amino acid-induced insulin release. VI. Metabolic interaction of L-glutamine and 2-ketoisocaproate in pancreatic islets. Biochim. Biophys. Acta 677: 39-49, 1981.

31. Malaisse, W. J., A. Sener, F. Malaisse-Lagae, M. Welsh, D. E. Matthews, D. M. Bier, AND C. IIEllerströM. The stimulussecretion coupling of amino acid-induced insulin release. X. Metabolic response of pancreatic islet to $\mathrm{L}$-glutamine and L-leucine. $J$. Biol. Chem. 257: 8731-8737, 1982.

32. Malaisse-Lagae, F., and W. J. Malaisse. Insulin release by pancreatic islets. In: Methods in Diabetes Research, edited by J. Larner and S. L. Pohl. New York: Wiley, 1984, p. 147-152.

33. McGilvery, R. W. Biochemistry, a Functional Approach. Philadelphia, PA: Saunders, 1970, p. 373.

34. Openshaw, H., AND W. M. Bortz. Oxidation of glucose, acetoacetate, and palmitate in brain mince of normal and ketotic rats. Diabetes 17: 90-95, 1968.

35. Rorsman, P., and G. Trube. Glucose dependent $\mathrm{K}^{+}$-channels in pancreatic $\beta$-cells are regulated by intracellular ATP. Pfluegers Arch. 45: 305-309, 1985.

36. Senfr, A., F. Bi.achier, J. Rasschaert, A. Mourtada, F. MaLAISSE-LAGAE, AND W. J. MalaISSE. Stimulus-secretion coupling of arginine-induced insulin release: comparison with lysine-induced insulin secretion. Endocrinology 124: 2558-2567, 1989.

37. Sener, A., M.-H. Giroix, AND W. J. Malaisse. Impaired uptake of D-glucose by tumoral insulin-producing cells. Biochem. Int. 12: 913-919, 1986.

38. Sener, A., S. Kawazu, J. C. Hutton, A. C. Boschero, G. Devis, G. Somfrs, A. Herchuelz, AND W. J. Malaisse. The stimulussecretion coupling of glucose-induced insulin release. XXXIII. Effect of exogenous pyruvate on islet function. Biochem. J. 176: 217-232, 1978 .

39. Sener, A., F. Malaisse-Lagae, S. P. Dufrane, and W. J. MaLAISSE. The coupling of metabolic to secretory events in pancreatic islets. The cytosolic redox state. Biochem. J. 220: 433-440, 1984.

40. Sener, A., F. Malaisse-Lagae, ANd W. J. Malaisse. Stimulation of islet metabolism and insulin release by a nonmetabolizable amino acid. Proc. Natl. Acad. Sci.USA 78: 5460 5464, 1981.

41. Sener, A., F. Malaisse-Lagae, and W. J. Malaisse. The stimulus-secretion coupling of glucose-induced insulin release. II. Fnvironmental influences on L-glutamine oxidation in pancreatic islets. Biochem. J. 202: 309-316, 1982.

42. Williamson, D. H., P. Lund, And H. A. Krebs. The redox state of free nicotinamide-adenine dinucleotide in the cytoplasm and mitochondria of rat liver. Biochem. J. 103: 514-527, 1967. 